\title{
Preferenciastabilitás. Vásárlói preferenciák változásának vizsgálata vásárlás elött és vásárláskor ${ }^{1}$
}

\author{
Dörnyei Otilia' - Pethö Beáta' - Tarján Tamás² \\ 'Pannon Egyetem - ${ }^{2 B}$ Budapesti Gazdasági Egyetem
}

\section{A TANULMÁNY CÉLJA}

Kutatásunk célja, hogy a vásárlói preferenciák változását mérhetővé tegye a napi cikkek kategóriájában.

\begin{abstract}
ALKALMAZOTT MÓDSZERTAN
Első lépésként előzetesen online preferencia felmérést, ezt követően bolti kérdőíves preferencia megkérdezést, illetve szemkamerás vizsgálatot végeztünk, majd végül értékelő kérdőívet töltettünk ki a kutatásban résztvevőkkel. A vizsgálat tárgyát a gyorsan forgó napi fogyasztási cikkek köréböl választottunk. Ezekben az FMCG kategóriákban a vásárlói döntési folyamat egyszerü, legtöbbször rutinszerúnek nevezhető, így a preferenciák stabilitásának kimutatása annál bonyolultabb, hiszen a vásárlási döntéseket sokszor a mögöttes preferenciák határozzák meg, melyeknek a vásárló nincs tudatában. A döntések jelentős része közvetlenül bolton belül, a polcok előtt dől el, így az in-store környezet jelentős hatást gyakorol a választásra. A vizsgálatba bevont termékkategóriák: (1) szénsavas vagy rostos üdítő, (2) sör, (3) édesség, (4) tejtermék, (5) fogkrém.
\end{abstract}

\section{LEGFONTOSABB EREDMÉNYEK}

Az eredmények igazolták azon feltételezéseket, miszerint a nemek között szignifikáns eltérés figyelhető meg a vásárlási magatartásban, valamint hogy az egyes termékkategóriák preferenciastabilitása különbséget mutat. Legfontosabb megállapításunk, hogy a „termék minősége” mind a szabadon választott, mind a top 3 preferencia esetében valamennyi kategóriában szerepelt az első három hely valamelyikén, és ez az állítás semelyik másik preferenciára nem igazolódott. A „termék íze, ízesítése” állítás a vizsgált 4 élelmiszer kategóriánál mindegyik kérdésnél az első három helyezés valamelyikét foglalja el, azonban a fogkrémnél nem szerepel ez az állítás a toplistában.

\section{GYAKORLATI JAVASLATOK}

Az üzleti szférában a kategóriamenedzsment területén szolgálhat hasznos információval a kutatás annak tekintetében, hogy a magyar fogyasztó tudatos és a termékek minősége abszolút prioritást élvez a döntéseiben. Mindegyik mért élelmiszer kategóriában a top 3 preferencia listában minden esetben jelen van a minőség, mint elsődleges preferencia.

Kulcsszavak: fogyasztói preferenciák, preferenciastabilitás, in-store döntések, fogyasztói magatartás

DOI: https://doi.org/10.15170/MM.2019.53.EMOK.03

Köszönetnyilvánítás: A kutatást az NKFIH az OTKA K 116040 számú alapkutatási pályázat alapján támogatja. 


\section{BEVEZETÉS}

A vásárlói termékválasztással több tudományterület foglalkozik. A vásárlások során a döntéshozóknak különböző döntési szituációkban kell helytállniuk, függően a vásárlás komplexitásától, az alapvető vásárlási magatartást a vevő személyes igényei, preferenciái időről időre felülírják. Ahány vásárló, annyi vásárlási szokás, az erősen impulzív vásárlók például nagyobb valószínűséggel vásárolnak spontán; bevásárló listájuk rugalmasabb és hajlamosak a váratlan, hírtelen vásárlási döntésekre (Rook \& Fisher 1995). A rutin döntési helyzetektől egészen a bonyolult, kockázatos döntésekig a vásárlás folyamatának egy a célja, a termék vagy szolgáltatás kiválasztása és fogyasztása, illetve használata. Ahhoz, hogy a legjobb döntés szülessen, a vásárlónak több tényezőt mérlegelni kell, az üzlet kiválasztásától a márka-, majd termékválasztásig, és mivel a folyamat nem a boltban kezdődik, a vásárláshoz vezető út (path to purchase) is lényeges elem itt, ami az igény felmerülésétől egészen a termék elfogyasztása után történő értékelésig tart.

Az összegyüjtött információk segítségével - ami (ti. az információgyüjtés) a bonyolult döntéseknél sokkal több időt vesz igénybe - az egyén az észlelt kockázatát próbálja csökkenteni. A fentiekböl is látható, hogy amíg a fogyasztó eljut a döntésig, olyan folyamaton megy végig, amelyben több tényező is döntő szereppel bír. Az egyén termékpreferenciái így mérvadók a választás folyamatában. A gazdaságpszichológiai megközelítés szerint a fogyasztók preferenciái nagyban függnek a döntési helyzettől, azaz kontextusfüggőek (Coupe et al. 1998, Hoeffler \& Ariely 1999). A preferenciákat nem nevezhetjük stabilnak, hiszen emocionális, kontextuális vagy egy harmadik fél általi külső tényező is közvetlen befolyásolást gyakorolhat (Foxall \& Yani-de-Soriano 2005, Veres - Tarján 2018). Az eladáshelyi termékválasztás során, a bolti környezetben az előzetes preferenciák nagy eséllyel módosulhatnak vagy megváltozhatnak a különböző, vásárlót érő stimulusok hatására. A vásárlás előtti időszakban és közvetlenül a vásárláskor is már eltelik egy bizonyos idő, mely során egyes preferenciák alakulhatnak. Ezeket az instabil preferenciákat nemcsak a bolti stimulusok, de a vásárlás elött a vásárlót ért hatások (pl. információ) is mozgathatják. A preferenciák létrejöttének és változásának megértése ezért különösen fontos ahhoz, hogy egy instore döntést elöre jelezhessünk.

Számos kutatás szerint a vásárlói döntések jelentős hányada a boltban véglegesedik (Berger
\& Fitzsimons 2008, Hofmeister -Törőcsik 1996, Turley \& Chebat 2002, Pethő és tsai 2017), ami azt jelenti, hogy a kereskedőknek és a gyártóknak még a döntés pillanatában is van esélyük befolyásolni a vásárlót. A vásárlási helyzet előtt azonban már egy létező preferenciarendszerrel rendelkezik a fogyasztó (Bettman 1979), hiszen előzetes tapasztalatai és tanult sémái (Golovics 2015) alakítják a döntéseit, így ennek feltérképezése után a vásárlói döntések eséllyel jelezhetők elöre (Mérő 2007). A preferenciarendszer megértése és elörejelzése rendkívül bonyolult feladat, mivel a fogyasztó sok esetben nincs is tisztában saját preferenciáival. Sőt, vannak preferenciák, melyekröl nem is tud vagy gyakran épp ellentétesek azzal a kimenettel, melyet a rendelkezésre álló információk eredményeznének, ez az ún. szubjektív tapasztalati hatás. Ezért is nagyon nehéz annak felkutatása, hogy mely preferenciák határozzák meg az adott termék vagy épp márka választását. A preferenciának különböző szintjeit különböztethetjük meg (Hlédik 2011), melyek együttesen határozzák meg a fogyasztó választását.

A közgazdasági értelemben vett kinyilvánított preferenciák (expressed preference) a fogyasztók kinyilvánított viselkedése (válasz vagy cselekvés) alapján határozhatók meg, míg a mögöttes preferencia a pszichológiai megközelítést jelenti (Warren et al. 2011). A nem tudatos, más néven mögöttes preferenciák (underlying preferences) ugyan nem láthatók, de hatással vannak döntéseinkre, determinálják a termékválasztást. A kinyilvánított preferenciák a fogyasztók megkérdezése útján határozhatók meg, a preferenciasorrend pedig a jószágkosarak összehasonlításával állítható fel. A mögöttes preferencia a fogyasztók azon látens, mögöttes hajlamát mutatja, mellyel kívánatosabbnak vagy elutasítottnak értékelnek egy márkát vagy terméket egy másikkal szemben. A mögöttes preferenciák pontos feltárása nem lehetséges (Sen 1973), nem nyerhető ki kutatásokkal. A lekérdezéses módszerek csupán csak a fogyasztók saját mögöttes preferenciákról való vélekedését (vélt preferenciák) rögzítik (Veres - Tarján 2018), melyek valódisága nem ellenőrizhetö. Kutatásunk esetében a kifejezett (stated) preferenciákat mértük. Ezek a fogyasztók kérdőives megkérdezésével határozhatók meg (Hlédik 2012). A kifejezett preferencia a fogyasztó hipotetikus válaszainak sémáira támaszkodik. A hangsúly azon van, hogy az egyén mit mond, nem azon, mit tesz.

A fogyasztói preferenciák gyakran instabilnak nevezhetők. Az instabilitást jellemzően a kontextushatások változásai okozzák. A vásárlókban megtörténhetnek ún. preferenciafordulások, melyek 
módosítják az előzetes elgondolásokat. Ezek a fordulások általában a lehetséges opciók eltérö bemutatása (pl. gondoljunk itt a keretezési hatásra), vagy a korlátozott információfeldolgozás, valamint az előzetes tapasztalat hiánya révén alakulnak ki. A vásárlók sok esetben az előzetes tapasztalataikra alapozva választanak, ha a döntéskor nem rendelkeznek megfelelő attribútum információkkal. A preferencia instabilitás eredményezi a márkalojalitás hiányát vagy épp a márkákkal szembeni közömbösséget. Az instabilitás föleg komplex termékek esetében figyelhető meg, ahol a döntések bonyolultak és megfelelő tájékozódást igényelnek. Mivel az instore döntések kontextusfüggőek, a preferencia instabilitást oly módon írhatjuk le, hogy „a vásárlási szituációt megelőzően kialakult preferenciarendszert összevetjük azzal, amit a fogyasztó a vásárlási döntéssel kinyilvánít" (Veres-Tarján, 2018). Meg kell azonban említeni a diszpreferenciák hatását is, hiszen ezek erősen korlátozzák, sőt egyes esetekben irányítják a választást. Az egyén egyes attribútumokat vagy attribútumszinteket semmiképpen sem akar választani, sőt elzárkózik azon termékek, szolgáltatások fogyasztástól, melyekre az általa diszpreferált attribútumok jellemzőek (pl. márka diszpreferenciák). Léteznek olyan helyzetek is, melyekben az egyén kötődik a terméküzenethez, vagy szereti a márkát, de valamely rá vonatkozó diszpreferencia kizárja a választásai köréből. Egyes szituációkban a fogyasztói viselkedésében tudatos ellentmondás figyelhető meg (Neulinger és tsai 2010), mely során a társadalmi rétegződéstől és jövedelmi helyzettől független módon a választást elsősorban az egyén vélt preferenciái határozzák meg. Az általános alapmodellek szerint a kialakult, standard preferenciák határozzák meg a választást, de helyzetfüggő és inkonzisztens választások is kialakulhatnak. A standard és a szituatív választás között átmenet jöhet létre például a marketingkommunikáció hatására (Pethő 2019).

\section{ANYAG ÉS MÓDSZER}

A kutatási minta nagysága 83 fö. A felmért alanyok életkorban 20 és 65 év közötti, napi bevásárlásért felelős személyek, akik előzetes rekrutálással kerültek a mintába. Az adatrögzítés két helyszínen történt, egy vidéki megyeszékhelyen és Budapesten. A kísérlet helyszíne közepes méretü kényelmi szupermarket kategóriába tartozó kiskereskedelmi egység volt. A fogyasztók előzetes preferenciáit egy online kérdőív segítségével mértük fel, amelyhez a SurveyMonkey internetes platformot használtuk. A részvevőknek egyedi emailen kiküldött kérdőívet kellett kitölteni, ezzel mértük a hosszú távú preferenciákat. Ezután a kiválasztott boltokba hívtuk a részvevőket, ahol a vizsgálat megkezdése előtt ismételten lekérdeztük a preferencia kérdőívet, ezzel kívántuk mérni a rövid távú preferenciákat. A kutatás nem tudatos viselkedést mérő oldalát szemkamerás méréssel valósítottuk meg. A résztvevőkre kalibráltuk a szemkamerát, majd arra kértük öket, hogy az előzetesen kiválasztott 5 napi cikk kategóriából vásároljanak preferenciáik és igényeik szerint. A vásárlást követöen egy elözetesen kiválasztott polcon - tájékozódási céllal - célirányos megfigyelést végeztünk. A polcon a szemkamera tartozékaként müködő markerekre gyüjtött adatok segítségével hőtérképet kívánunk rajzolni a későbbiekben.

A kutatás utolsó lépéseként a megvásárolt termékeket egyedileg rögzítettük, majd azt vizsgáltuk, hogy miért azt az adott terméket választotta a résztvevő. A kérdőív minden egyes kiválasztott termékre kiterjedt, és ha valaki nem a megszokott termékét vásárolta, ennek okát is kérdeztük. A bolti stimulusok hatékonyságának vizsgálata céljából az instore eszközök észlelésére egy külön kérdést fogalmaztunk meg. A kérdőív utolsó kérdése alapján attitüdalapú szegmentációt kívánunk elvégezni, azzal a céllal, hogy feltárjuk, van-e összefüggés a preferenciák változása és az egyén vásárlási attitüdjei között.

A kutatás helyszínei és ideje:

- Közepes nagyságú megyeszékhely, 1.200 négyzetméteres kényelmi szupermarket kategóriába tartozó kiskereskedelmi egység. 2017. július 9-12.

- Budapest, 1.200 négyzetméteres kényelmi szupermarket kategóriába tartozó kiskereskedelmi egység. 2017. augusztus 22-23. és 28-29.

\section{A kutatás menete}

Az elemzések sorát az előzetes online kérdőív és a vásárlás elött közvetlenül a boltban lekérdezett kérdőívek preferenciavizsgálatával kezdtük. A preferenciákat kétféleképpen vizsgáltuk.

- Egyrészt egy előzetesen összeállított és tesztelt listát készítettük, amelyből szabadon választhatták ki a válaszadók a számukra fontos jellemzőket. A preferencialista 10 állandó jellemzőből állt, majd kategóriánként 4-9, a termékcsoportra jellemző állítást tartalmazott. Ennél a szabadon választható listánál kategóri- 
ánként átlagban 4,69-es értéket kaptunk, amely az üdítő italok esetében mért 5,06-os legmagasabb értéktöl a legalacsonyabbnak mért 3,90 sör értékig terjedt.

- Majd ezután egy másik kérdésben, de ugyanezen listából kellett az első, a második és harmadik számukra legfontosabbat kiválasztani a kutatásban résztvevöknek.

A kérdések jelölésére az alábbi változóneveket vezettük be:

Pkategórianév $=$ az előzetes online kérdőív, szabadon választott lista.

Pkategórianév3 = az előzetes online kérdőív 3 legfontosabb preferencia.

Qkategórianév = bolti kérdőív, szabadon választott lista.

Qkategórianév3 = bolti kérdőív, 3 legfontosabb preferencia.

Első lépésként egy négyes mátrixot képeztünk mind az öt vizsgált termékkategóriára (ü=üdítő, $\mathrm{s}=$ sör, t=tejtermék, é=édesség, $\mathrm{f}=$ =fogkrém), ahol az előzetes online kérdőív két kérdése (Pkategórianév vs. Pkategórianév3) a bolti kérdőív két kérdése között (Qkategórianév vs. Qkategórianév3), majd párban az elökérdőív és a bolti kérdöív szabadon választott preferencialistái között (Pkategórianév vs. Qkategórianév), majd az előkérdőív és a bolti kérdőív legfontosabb 3 preferenciája között (Pketegórianév3 vs. Qkategórianév3).

\section{Kutatási kérdések}

Kutatásunkban a következő kérdésekre kerestük a választ:
- Stabilnak nevezhetök-e a preferenciák a vizsgált kategóriákban?

- Kimutatható-e szignifikáns különbség a preferenciaváltozásokban nemek tekintetében?

- Az egyes termékkategóriák mutatnak-e szignifikáns különbséget egymáshoz képest a preferenciastabilitás tekintetében?

- Elkülöníthetők-e különféle vásárlói magatartáscsoportok az életkor függvényében?

\section{KUTATÁSI EREDMÉNYEK}

A preferenciák változásában szignifikáns eltérés tapasztalható női és férfi vásárlók között. A korrelációt nem csak az egész adatbázisra számoltuk, hanem válaszadónként is. Három demográfiai szempont (nem, kor, lakóhely) szerint is kettéosztottuk a válaszadókat:

- nem: férfi ↔ nő;

- $\quad$ kor: 40 év alatti $\leftrightarrow 40$ éves vagy több; és

- lakóhely szerint: Budapest $\leftrightarrow$ megyeszékhely alapján.

Mindhárom kettéosztás szerint homogenitásvizsgálatot végeztünk, vagyis, hogy jöhet-e ugyanabból az eloszlásból a két alminta? A választ a Pearson-féle khi-négyzet próbával kerestük; 5 százalékos, ill. 10 százalékos hibaszinten szignifikánsan eltérnek-e egymástól, vagy sem. A minta méretéből adódóan a 10 százalékos hibahatárt is elfogadhatnánk, de a kutatói pontosság szempontjából az 5 százalékos hibahatárt részesítettük előnyben (1. táblázat).

\section{1. táblázat: Szignifikáns eltérések férfiak és nők között a vizsgált termékkategóriákban}

\begin{tabular}{|l|l|l|l|l|l|l|l|l|l|l|l|l|l|l|l|l|}
\hline F-N & QSs & PQS & PSs & PQs & QTt & PQT & PTt & PQt & QÉé & PQÉ & PÉé & PQé & QFf & PQF & PFf & PQf \\
\hline $\begin{array}{l}\text { Korrel } \\
1+2\end{array}$ & 0,48 & 0,54 & $\mathbf{0 , 4 6 *}$ & 0,4 & 0,5 & $\mathbf{0 , 5 9 *}$ & $\mathbf{0 , 4 9}$ & 0,35 & 0,51 & 0,6 & $\mathbf{0 , 5}$ & 0,37 & 0,46 & 0,54 & $\mathbf{0 , 4 4 *}$ & 0,32 \\
\hline $\begin{array}{l}\text { Korrel. } \\
\text { 1 (ffi) }\end{array}$ & 0,5 & 0,46 & $\mathbf{0 , 3 6}$ & 0,37 & 0,47 & $\mathbf{0 , 5 3}$ & $\mathbf{0 , 4 3}$ & 0,33 & 0,46 & 0,49 & $\mathbf{0 , 4 4}$ & 0,3 & 0,46 & 0,4 & $\mathbf{0 , 4 2}$ & 0,33 \\
\hline $\begin{array}{l}\text { Korrel. } \\
\text { 2 (nö) }\end{array}$ & 0,48 & 0,58 & $\mathbf{0 , 5}$ & 0,42 & 0,51 & $\mathbf{0 , 6 1}$ & $\mathbf{0 , 5 1}$ & 0,36 & 0,53 & 0,64 & $\mathbf{0 , 5 2}$ & 0,4 & 0,46 & 0,59 & $\mathbf{0 , 4 5}$ & 0,31 \\
\hline c2 & 7,08 & 8,73 & 11,12 & 1,75 & 10,3 & 14,55 & 17,82 & 0,93 & 5,81 & 2,2 & 15,3 & 8,57 & 9,32 & 3,59 & 26,89 & 5,3 \\
\hline $\begin{array}{l}\text { c2 krit. } \\
\text { (p=0,05) }\end{array}$
\end{tabular}

Forrás: saját szerkesztés 
5 százalékos szinten 5 összehasonlítási párban találtunk szignifikáns eltérést:

- A sörnél a bolti kérdőív szabadon választott preferencia listájánál és a top 3 preferencia vizsgálatánál találtunk szignifikáns különbséget a férfiak és nők között: a nők 0,50-es korrelációja áll szemben a férfiak 0,36-os szintjével.

- A tejtermékekénél a szabadon választott lista és a top 3 preferencia estében: a nők 0,51-os korrelációja áll szemben a férfiak 0,43-as szintjével az előzetes kérdőívnél.

- Ugyanígy a tejtermék kategóriánál az előzetes kérdőív és a bolti kérdőív teljes preferencia listáján mért 0,61-es női csoport adata szignifikánsan eltér a férfiak 0,53-as mért értékétöl.

- Édesség esetében a szabadon választott lista és a top 3 preferencia estében: a nök 0,52-es korrelációja áll szemben a férfiak 0,44-as szintjével az előzetes kérdőívnél.

- A fogkrém esetében az elözetes kérdőív szabadon választott lista vs. top 3 preferencia esetében 0,42 férfiak vs. 0,45 a nök korrelációja, a különbség a szórás miatt azonban szignifikáns, már 5 százalékos szinten is.

\section{Kategóriánkénti tanulságok}

A hosszú távú preferencia vizsgálatában szignifikáns különbséget találtunk mindkét szinten (5 és 10 százalékos hibahatárnál), a hosszú távú preferenciát illetően a sörnél, tejtermékeknél, az édességeknél, a fogkrémnél is. Vagyis ebben a négy vizsgált kategóriában jelentős eltérést találtunk a nők és férfiak preferenciájában, azzal együtt, hogy a mért eloszlások is különböznek, míg az üdítőnél nem tudunk ilyen nemek közötti eltérést kimutatni.

Életkor alapján elsőre a minta megfelezése mellett döntöttünk, ezért egy közel fele-fele arányban 39 év alattiak vs. 40 év felettiek elemzését végeztük el. Az eredmények alapján 5 százalékos szignifikanciaszint mellett nem találtunk jól magyarázó eltérést, 10 százalékos szignifikanciaszint mellett, jelzésértékünek vettük, hogy a sör kategória esetében a Q és $\mathrm{P}$ top 3 preferencia esetében a 39 évnél fiatalabbak esetében erősebb a korreláció, mint a 40 felettieknél.

Feltételezésünk szerint az életkortól valamilyen változó magyarázót vártuk, ezért a marketingszakmában újabban alkalmazott generációs felosztást is kipróbáltuk. A generációs elmélet alapján az 1965 előtt születetteket a baby boomer generációhoz soroljuk, az 1965 és 1980 között születettek az X generáció tagja, míg az 1980 után születettek az Y generációhoz tartoznak. Az új korcsoport bontásban 5 százalékos szignifikanciaszint mellett nem találtunk eltérést, így a generációs elmélet eltéréseit ezen a mintán nem tudtuk igazolni.

Két településen, Budapesten és egy megyeszékhelyen történt a mérésünk, két viszonylag hasonló adottságú kényelmi szupermarketben. A városi lét és életmód, ill. a bolti készlet kínálatának hasonlóságát véljük felfedezni, hogy 5 százalékos szignifikanciaszinten, csak egy helyen, a fogrém kategória előzetes és bolti, szabad választású preferenciájában találtunk szignifikáns eltérést (de ezen kívül 10 százalékos szinten sem találtunk eltérést a két város között). A mért, mind 5 százalékos, mind 10 százalékos korrelációs szint 0,54ös eredményt hozott mind Budapesten, mind a megyeszékhelyen, viszont a minta eloszlása nem azonos. Az eloszlás alapján azt találtuk, hogy a két azonos értékü átlag nagyon eltérő eloszlásból adódott. A megoszlás Budapest vs. megyeszékhely, amely ugyan azonos szintü korrelációt jelez, mégis szignifikáns eltérést mutat az eloszlás miatt.

\section{KÖVETKEZTETÉSEK ÉS JAVASLATOK}

Az adatok matematikai-statisztikai elemzései alapján megállapítjuk, hogy egyes vizsgált változók szignifikáns kapcsolatot mutatnak. Az eredmények igazolták azon feltételezéseket, miszerint a nemek között szignifikáns eltérés figyelhetö meg a vásárlási magatartásban, valamint hogy az egyes termékkategóriák preferenciastabilitása különbséget mutat.

A preferenciák változásában a nemek alapján mutatkozik leginkább szignifikáns eltérés, ami a föbevásárlók arányának megoszlásával magyarázható. A napi fogyasztási cikkek vásárlói döntő részben a nök, emiatt több információval, nagyobb tapasztalattal és tudatossággal kezdenek neki a bevásárlásnak, mint a férfiak.

A vizsgált 5 kategóriában a preferenciák stabilitását a szabadon választott lista majd a top 3 preferencia kiválasztásával vizsgáltuk. A szabadon választott listák összességében átlagosan 5,46 állítást jelöltek meg a résztvevők. Az összehasonlíthatóság miatt mindkét preferencialistából top 3-as összesítést képeztük. Legfontosabb megállapításunk, hogy a „termék minősége" mind a szabadon választott, mind a top 3 preferencia esetében valamennyi kategóriában szerepelt az első három hely valamelyikén, és ez az állítás semelyik másik 
preferenciára nem igazolódott. A „termék íze, ízesítése" állítás a vizsgált 4 élelmiszer kategóriánál mindegyik kérdésnél az első három helyezés valamelyikét foglalja el, azonban a fogkrémnél nem szerepel ez az állítás a toplistában.

A fogkrém, mint a vizsgálat egyetlen vegyi áru kategóriája más mintázatot mutat a preferenciák tekintetében, mint a 4 élelmiszer kategória. A fogkrém esetében az ,általam már kipróbált termék" jellemzőt találtuk legerösebbnek a preferenciák tekintetében. Ennek okát abban látjuk, hogy a fogkrém nem egy azonnali elfogyasztásra való termék, és a korábbi termékhasználat újabb vásárlást eredményezhet, hiszen a fogyasztó korábbi tapasztalatai segítségével csökkenti döntési kockázatát.

$\mathrm{Az}$ édesség kategória esetében a „termék minősége" és a „termék íze, ízesítése" mellett a „termék fajtája” (cukorka, csoki, praliné, keksz, sütemény...) valamennyi vizsgált esetben a toplista tagja kizárólagosan. Hazai szakértői vélemények szerint a kategória fogyasztását jellemzően meghatározzák az adott szegmens fogyasztói szokásai és kulturális-tradicionális mivolta. Emellett rendkívül széles márka és terméktípus kínálat található már a legkisebb kiskereskedelmi egységben is, így a fogyasztók itt nagyobb jelentőséget tulajdonítanak a választásnak.

A „termék típusa” állítás a sör esetében került fel a toplistába, markánsabban, mint pl. az „alkoholtartalom”, vagy az üdítők esetében a „cukortartalom”, vagy a tejtermékeknél a „zsírtartalom”. Ezek a preferenciák jellemzően a negyedik-hatodik helyezést foglalják el a preferenciák listájában.

Az ,akciók keresése” alig jelent meg a listákban, ennek okát az affluens válaszadói csoportban és a kényelmi szupermarket, mint helyszín adottságaiban látjuk.
$\mathrm{Az}$ eredmények nem igazolták azt a feltételezést, hogy az életkor alapú szegmentáció végrehajtható. Nem találtunk szignifikáns eltérést ugyanis a vásárlói magatartásban az egyes életkorok függvényében. A következökben szándékunkban áll nagyobb mintán elvégezni a kutatást, ahol jobban szegmentálható nem és életkor csoportokat képezhetünk. Tekintettel a kutatás módszertanára, nem zárhatjuk ki azt a torzító hatást, hogy a kutatás két nagyvárosi településre és a kényelmi szupermarket csatornára vonatkozott.

$\mathrm{Az}$ üzleti szférában a kategóriamenedzsment területén szolgálhat hasznos információval a kutatás annak tekintetében, hogy a magyar fogyasztó tudatos és a termékek minősége abszolút prioritást élvez a döntéseiben. Mindegyik mért élelmiszer kategóriában a top 3 preferencia listában minden esetben jelen van a minőség, mint elsődleges preferencia. 


\section{HIVATKOZÁSOK}

Berger, J., Fitzsimons, G. (2008), "Dogs on the Street, Pumas on Your Feet: How Cues in the Environment Influence Product Evaluation and Choice", Journal of Marketing Research, XLV February, 1-14 DOI: https://doi.org/10.1509/ jmkr.45.1.1

Bettman, J. R. (1979), "Issues in Research on Consumer Choice". In Advances in Consumer Research. 6, Wilkie, W. L. (Ed), Association for Consumer Research, 214-7 DOI: https://doi. org $/ 10.2307 / 1250155$

Coupe, E., Irwin, J. R., Payne, J. W. (1998), "Product Category Familiarity and Preference Construction", Journal of Consumer Research, 24 March, 459-68 DOI: https://doi. org/10.1086/209521

Foxall, G. R., Yani-de-Soriano, M. M. (2005), "Situational influences on consumers' attitudes and behavior", Journal of Business Research, 58 518-25 DOI: https://doi.org/10.1016/s01482963(03)00142-5

Golovics J. (2015), „Korlátozott racionalitás és altruizmus: behaviorizmus a közgazdaság-tudományban", Hitelintézeti Szemle, 14 2, 158 172

Hlédik, E. (2011), Fogyasztói preferenciákat befolyásoló tényezők komplex termékek esetén, in Fojtik J. (szerk.): Felelös marketing. A Magyar Marketing Szövetség Marketing Oktatók Klubja 17. országos konferenciájának elöadásai. Pécsi Tudományegyetem Közgazdaságtudományi Kar: Pécs. 795-804 ISBN: 978963 6423

Hlédik, E. (2012), Termékjellemzök és preferenciák. Szegedi Tudományegyetem Gazdaságtudományi Kar, Doktori értekezés

Hoeffler, S., Ariely, D. (1999): "Constructing Stable Preferences: A Look into Dimensions of Experience and their Impact on Preference Stability", Journal of Consumer Psychology, 8 2, 113-39 DOI: https://doi.org/10.1207/ s15327663jcp0802 01

Hofmeister-Tóth Á. - Törőcsik M. (1996), Fogyasztói magatartás, Nemzeti tankönyvkiadó Budapest

Mérő L. (2007), Mindenki másképp egyforma. Budapest, Tercium Kiadó

Neulinger Á. - Simon J. - Kelemen K. - Hofmeister-Tóth Á. - Bódi E. (2010), „Fogyasztói magatartás a hazai utazási szolgáltatások piacán - A hibrid vásárlói magatartás vizsgálata”, Vezetéstudomány, 41 6, 50-62
Pethő B. (2019), Preferencia-alapú termékválasztási magatartás kísérletes in-store kutatása, Pannon Egyetem Gazdaságtudományi Kar, Doktori értekezés.

Pethő B. - Veres Z. - Bátor A. - Tarján T. (2017), „Preferencia-alapú termékválasztási magatartás kísérletes instore kutatása szemkamera segítségével", Marketing és Management, LI. EMOK Különszám, 28-37

Rook, D. W., Fisher, R. J. (1995), ’Normative Influences on Impulsive Buying Behavior", Journal of Consumer Research, 22 3, 305-13 DOI: https://doi.org/10.1086/209452

Sen, A. (1973), 'Behavior and the Concept of Preference" Inaugural lecture delivered at the London School of Economics on 1 February 1973. Economica, New Series, 40 159, 241-259 DOI: https://doi.org/10.2307/2552796

3Turley, L. W., Chebat, J. C. (2002), ’Linking Retails Strategy, Atmospheric Design and Shopping Behavior", Journal of Marketing Management, 18 125-44 DOI: https:/doi. org/10.1362/0267257022775891

Warren, C., McGraw, A. P., Van Boven, L. (2011), "Values and preferences: Defining preference construction", Interdisciplinary Reviews: Cognitive Science, 2 193-205. DOI: https://doi. org/10.1002/wcs.98

Veres Z. - Tarján T. (2018), „Szekvenciális fogyasztói termékválasztás döntési kontinuuma", Közgazdasági Szemle, 65 5, 525-50 DOI: https://doi.org/10.18414/ksz.2018.5.525 
Dörnyei Otília $\mathrm{PhD}$ hallgató dornyei.otilia@gtk.uni-pannon.hu

Pethő Beáta PhD hallgató pethobeata@gmail.com

Pannon Egyetem

Gazdálkodás- és Szervezéstudományi Doktori Iskola

Tarján Tamás CSc

Tarjan.Tamas@uni-bge.hu Budapesti Gazdasági Egyetem

Kutatóközpont

\section{Preference Stability \\ Investigating customer preferences before and at the purchase}

\section{THE AIMS OF THE PAPER}

The aim of our reasearch is to measure consumer preferences in Fast Moving Consumer Goods market.

\section{METHODLOGY}

First we conducted an online survey to measure long-time preferences, followed by in-store questioning still on preferences. As third, eye-tracking measurment was conducted while we finished with an evaluating questionnaire with those who participated in our research. Our spot of selection focused on Fast Moving Consumer Goods (FMCG). By those daily goods the consumer journey is rather short, kind of routine-wise. Therefore prove on stability of preferences may be difficult as underlaying preferences have stronger inpact what consumer may be not aware of. Decisions are made in-store at the self mainly, therefore in-store stimuli have a strong effect on purchase decision. Our examinded categories were: (1) carbonated and non-carbonated soft drinks, (2) beer, (3) sweets, (4) dairy products, (5) toothpaste.

\section{MOST IMPORTANT RESULTS}

Results approved our hypothesis of having a significant difference in purcchase behaviour between male and female when doing daily grocery shopping and next to that preference stability shows a clesar differencee when different categories are examined.

Our main finding is that „quality of product” preference item proved to be in top 3 by each of the 5 examined FMCG categories in case of both spontaneous open list and promted top 3 closed list while this statement is not proved to be true for any of the other preferences included in our survey. „Taste/flavour of product" proved to be in the first 3 position in case of the examined four food categories while in case of toothpaste this preference was not nominated to the toplist.

\section{RECOMMENDATIONS}

In the professional business our research may help category management with practical information on how much Hungarian consumers conscious are and how much ,quality of product" an absolute priority means when deciding on daily grocery shopping. In each of our 4 examined food categories „quality" is ranked as one of the top 3 preferences.

Keywords: consumer preferences, stability on preferences, in-store decision making, consumer behaviour

Acknowledgement: The research is supported by Hungarian Scientific Research Fund (No. OTKA K 116040) of National Research, Development and Innovation Office. 